\title{
A cross sectional survey of personal hygiene positive behaviour related to COVID-19 prevention and control among Indonesian communities
}

Fatma Lestari ( $\nabla$ fatma@ui.ac.id)

Occupational Health and Safety Department, Faculty of Public Health, Universitas Indonesia

Abdul Kadir

Occupational Health and Safety Department, Faculty of Public Health, Universitas Indonesia

Muhammad Idham

Indonesia National Occupational Safety \& Health Council

Fahrul Azwar

Indonesia National Occupational Safety \& Health Council

Ganis Ramadhany

Indonesia National Occupational Safety \& Health Council

Fredy Sembiring

Indonesia National Occupational Safety \& Health Council

Ghazmahadi Ghazmahadi

Indonesia National Occupational Safety \& Health Council

Abdul Hakim

Indonesia National Occupational Safety \& Health Council

Robiana Modjo

Occupational Health and Safety Department, Faculty of Public Health, Universitas Indonesia

Baiduri Widanarko

Occupational Health and Safety Department, Faculty of Public Health, Universitas Indonesia

Yuni Kusminanti

Occupational Safety, Health and Environmental Unit (OSHE), Universitas Indonesia

\section{Research Article}

Keywords: COVID-19 prevention, COVID-19 control, Indonesian communities, personal hygiene, behaviors

Posted Date: January 7th, 2021

DOI: https://doi.org/10.21203/rs.3.rs-132920/v1

License: (c) (i) This work is licensed under a Creative Commons Attribution 4.0 International License. Read Full License 


\section{Abstract}

Background: The trend of COVID-19 confirmed cases has continually risen in Indonesia, this pandemic situation has affected several life sectors, including health sectors, education, economic, services, and employment sectors. Public health and social measures as recommended by Word Health Organization are required to be implemented in order to prevent the coronavirus disease spread. People's behaviours can also affect the spread of the COVID-19 virus. Public behaviours including proper personal hygiene and healthy life practices, the use of appropriate masks, and the application of good disinfectants have an important role in human's health and protection towards prevention and control of COVID-19 spreads. This study aims to perform a survey of public behaviour and best practices related to COVID-19 prevention and control among Indonesian communities.

Methods: A cross-sectional study was designed to collect information related to public behaviour related to COVID-19 prevention and control using an online survey. Respondents were gathered from 34 provinces in Indonesia through the Indonesia National Safety and Health Council network and Universities network. Respondents voluntarily submitted their response to a pre-designed online questionnaire. The collected data was then analyzed using SPSS 24.0.

Results: A total of respondents 771 subjects (male 386; female 385) were submitted their response. The results show that $96 \%$ of participants implementing positive behaviour of personal hygiene including wearing a mask when going outside their house and almost $67.3 \%$ of respondents sprayed a disinfectant in their house. The majority of participants hold a door handle (37.2\%) and desk (28.1\%) at frequency of more than six times a day. There were $8.2 \%$ of participants implementing good personal hygiene including hand washing at least once a day and maximum of more than six times after going to the toilet. At risk behaviour were conducted by respondents at which they touched part of their face at frequency once during an hour. It has been identified that male are less likely to perform better hand hygiene as opposed to female. In conclusion, study showed that positive behaviour of personal hygiene related to COVID-19 has been implemented among Indonesian communities. This result suggested that positive behaviour based on community based prevention and control need to be continually maintain in order to prevent and control COVID-19 spreads.

\section{Background}

Nowadays, Coronavirus Disease-2019 (COVID-19) has become major concern as pandemic around the world. A novel coronavirus is also known Severe Acute Respiratory Syndrome Coronavirus 2 (SARS-CoV-2). This virus firstly identified as an outbreak in Wuhan, Hubei, China on 31 December 20191,2. Moreover, the bat reservoir is thought to be causative agent for the emergence of SARS-CoV-2, which is one of the seven coronaviruses known to infect humans ${ }^{3}$.

Based on several studies, COVID-19 transmits humans to humans in several ways, namely droplets and contact routes ${ }^{4}$. Furthermore, this virus is transmitted through direct contact of a droplets from an infected person's airway that exhaled through coughs and sneezes. People can also become infected by touching a surface which contaminated by the virus and then followed by touching their face including their eyes, nose and mouth. The COVID-19 virus can stay on hard surface for up to several hours and days, yet it can be killed with the use of disinfectants ${ }^{5}$. World Health Organization (WHO) reported that SARS-COV-2 can be transmitted through the airborne. Hence, the transmission of virus has an important role in the rise of COVID-19 confirmed cases. On January 30, 2020, WHO designated COVID-19 as Public Health Emergency of International Concern (PHEIC) ${ }^{6}$.

The spread of COVID-19 has just emerged widely and rapidly ${ }^{7}$. Globally, World Health Organization recorded around $17,660,523$ total confirmed cases of COVID-19 in 216 countries with fatality cases of 680,894 deaths reported per 17 October $2020^{8}$. 
Indonesia, for instance, one of the countries affected by Covid-19. The government has confirmed as first case of Covid19 at March $2^{\text {nd }}, 2020^{9}$. The president Indonesia has issued a policy related to this diseases under Presidential Decree No. 12 of 2020 concerning the determination of Coronavirus Disease 2019 (COVID-19) as national disaster. Following by the formation of Gugus Tugas Percepatan Penanganan COVID-19 (Task Force for Rapid Response to Covid-19) ${ }^{10}$. Recently, COVID-19 cases in Indonesia, there are 361,867 total confirmed cases, total number recovered 285,324, and total number of death 12,511 people on 34 provinces. In addition, 8 provinces are being considered at high or very high risk, and 7 provinces at moderate risk. DKI Jakarta (26.1\% cases), East Java (13.6\%) and West Java (8.4\%) are categorized as three highest provinces due to Covid-19 cases $^{11}$. According to the data, the trend of covid-19 has continually increased. Hence, The Covid-19 pandemic situations has affected several sectors such as health, education, economic, services, employment sectors ${ }^{12}$.

In order to prevent the spread of virus, Indonesian government has implemented some regulations and policies such as several public health and social measures as recommendation from $\mathrm{WHO}^{8}$, including strengthening COVID-19 testing, isolation, treatment, and tracing. One of the regulation applied was Government Regulation No. 21 of 2020 concerning the Limitation of Large-Social Interactions in order to accelerate the COVID-19 control and prevention (31 March 2020). This social distancing is expected to reduce or even break the spread of COVID-19. Everyone should maintain a safe distance from others at least 2 meters, avoid close and direct contact with other people, and avoiding the crowded situation in the public situations. As a result, several policies has been released such as working and studying from home, health protocols policy including personal hygiene, workplace hygiene, community hygiene which have been implemented in various industries and educational institutions. Even though, there are some incompliance in the real situation which has been identified including some Indonesian people may disobey this policy. People are still doing crowded activities outside, or it is not uncommon to find them on vacation to several places and going to hometowns ${ }^{13}$.

People's behaviours can also influence the spread of the COVID-19 virus. Positive behaviours including frequent handwashing, proper personal hygiene and healthy life styles, wearing appropriate masks, and the application of disinfectants which could have an important role in human's health and safety. Therefore, it is very important to integrate the behaviours aspect in the implementation of the policies ${ }^{14}$. Hence, it can be said that the behavioural aspects has significantly contributed to COVID-19 prevention and control during the pandemic and several aspects such as social and cultural of dwellers have influenced the level of behaviour change ${ }^{15}$.

Although COVID-19 continues to spread, the community must take action to prevent further transmission, reduce the impact of this outbreak and support measures to control the disease ${ }^{8}$. Positive healthy behaviour has triggers researchers to further analysis how is the nature of Indonesian people with positive behaviors and deal with the Covid-19 virus pandemic and how to address with the situation. This study aims to conduct a cross sectional survey of positive personal hygiene behaviour related to COVID-19 prevention and control among Indonesian communities.

\section{Methods}

\section{Study Design and Participants}

The research was conducted based on study design of a cross sectional survey. The respondents of this survey were from 32 provinces in 6 (six) mainlands in Indonesia which derived from Indonesia National Safety \& Health Council network and Universities network. Data were collected using an online survey questionnaire. The survey was conducted from $31^{\text {st }}$ April to $29^{\text {th }}$ May 2020, a period at which most of provinces in Indonesia particularly in Java Island was endorsed to stay home based on the government of provinces policy to conduct limited Large Scale Social Restrictions or PSBB (Pembatasan Sosial Berskala Besar). In order to ensure the validity and accuracy of the data collected, the instruments were validated and check its reliability by conducted a preliminary survey. All subjects have been informed 
about the survey objectives, the benefit of the survey for the community, and signed a written informed consent prior to voluntarily join the study. Informed consents consist of the information of the purposed of study, ethical approval, and terms of condition. The researchers applied the informed consent during the study with the principle of beneficial, no harm, confidential, justice and voluntary participants. Hence, several information should be agreed by participants prior data collection. Particularly, if the participant under 18 years old, those have to ask permission to their parent or legal guardian. If it does not meet the criteria, the system automatically stops the survey. The informed consent has been describe in details during the Ethics Approval and Consent before the study conducted, and has been approved under the Ethics Approval Letter from Ethics Committee Faculty of Public Health, Universitas Indonesia Number: Ket-

435/UN2.F10.D11/PPM.00.02/2020. Hence, all methods for this study were performed in accordance with the relevant guidelines and regulations of ethical committee. No animal and human body handling were involved for this present study.

\section{Questionnaire}

A self-reported questionnaire of Coronavirus prevention and control was administrated by researchers and distributed using google forms: http://tiny.cc/z0d7lz [see additional File 1]. The questionnaire consists of 5 parts: 1) demographic information (age, gender, occupation, provinces, and hometown in JABODETABEK, where the vibrant area in Indonesia); 2) activities during COVID-19 pandemic (type of work, indoor and outdoor activities); 3) personal hygiene (the use of masker, disinfectant, hand sanitizer, behavior in touching face, and hand-washing); 4) the perception of COVID-19; 5) the source of COVID-19 related information and supporting aspects in facing COVID-19. As a guideline for developing a survey tools, the study referred to Covid-19 Prevention and control protocol published by Ministry of Health of Indonesia. The link of questionnaire, then, had been shared through Indonesia National Safety Council network, universities network, and shared on social media such as online website, Facebook, Instagram, and WhatsApp.

\section{Data and Statistical Analysis}

SPSS 24.0 was utilized to compute and analyse the data. The descriptive and binary variables were performed as a percentage. Regarding the questionnaire of perception of COVID-19 which had been developed as Linkert scales (strongly not suitable - strongly appropriate), the validity and reliability were tested. As a r statistics or correlated itemcorrelation > r table (0.4438) $(\mathrm{Cl}: 95 \%)$ and Cronbach's Alpha $=0.903$, it means that the items of questionnaire had a good concurrent validity. In addition, Chi-square test was performed to determine whether there is a significant relationship between categorical variables for characteristic of demographic and personal hygiene based on $p$ value $<0.05$ and odds ratio (OR) with $95 \%$ confidential interval (Cl).

\section{Ethical Consideration}

The study was reviewed and approved by the ethics committee of the Research and Community Engagement of Faculty of Public Health, Universitas Indonesia under Ethics Approval Letter No: Ket-435/UN2.F10.D11/PPM.00.02/2020.

\section{Results}

\section{Subjects Demographic Characteristics}

The total of 784 subjects were responded in this survey. After filtering and cleaning the data, 771 valid questionnaires were obtained and 13 samples were excluded because of inappropriate responses. The participants originated from 32 of 34 provinces that lived in 6 main islands of Indonesia, the majority were Java (69.6\%) and non-Java (30.4\%). The majority respondents derived from the area in Java particularly they were based on Jakarta 153 (19.8\%), West Java, 152 (19.7\%), East Java 91 (11.8\%) and Yogyakarta 80 (10.4\%), while the majority of participant in non-Java island was 
Sumatera (14.1\%). The mean age was $>35$ years (Standard Deviation: 1.94). In addition, the participants were relatively almost balance between male and female, which was cited at $50.1 \%$ and $49.9 \%$ respectively. The most participant were employment (69.9\%) and worked in private companies (24.4\%). 55.5\% of participants stayed at the centre of Indonesia, which is JABODETABEK (Jakarta, Bogor, Depok, Tangerang, Bekasi). Table 1. below depicts the characteristic of study respondents in detail:

\section{Table 1. The Demographic information of respondents $(n=771)$}

\begin{tabular}{|ll|}
\hline Characteristics & $\mathbf{n}(\%)$ \\
\hline Age [Mean (SD), years] & $35-40 \pm 1.94$ \\
$<35$ & $297(38.5)$ \\
\hline Gender & $474(61.5)$ \\
Male & \\
Female & $386(50.1)$ \\
Educational Background & $385(49.9)$ \\
Lower Education & $88(11.4)$ \\
Higher Education & $683(88.6)$ \\
Occupation & \\
Unemployment & $232(30.1)$ \\
Employment & $539(69.9)$ \\
\hline Major Islands & \\
Java & $537(69.6)$ \\
Non-Java & $234(30.4)$ \\
\hline Domicile in (JABODETABEK) & \\
Yes & $428(55.5)$ \\
No & $343(44.5)$ \\
\hline
\end{tabular}

\section{Participant's Activities}

As far as typical activities during COVID-19 situation was concerned, $94 \%$ of participants did not take a trip to their home town. Mostly, $59.1 \%$ of participants have been working, where the kind of job activities was working from home (67\%). In term of feeling bored, respondents said they felt that situation as of $47 \%$. There were $28 \%$ of responses, however, tend to feel in between bored or not (Table 2). Moreover, respondents stated that working (30\%), cooking (24\%), studying (19\%) and online lecturer (13\%) were the main indoor activities (Figure 1).

Table 2. Respondents typical activities during COVID-19 pandemic 


\begin{tabular}{|ll|}
\hline Items & $\mathbf{n}(\%)$ \\
\hline Take a trip to home town (Mass Exodus) & \\
Nes & $49(6)$ \\
\hline Types of work during COVID-19 & $722(94)$ \\
Work from Office & \\
Work from Home & $252(32.7)$ \\
Feeling bored stay at home during pandemic & $519(67.3)$ \\
Yes & $365(47)$ \\
No & $195(25)$ \\
Maybe & $213(28)$ \\
\hline
\end{tabular}

Figure 2. illustrates the outdoor activities were still being conducted in pandemic of coronavirus. The majority of activities were buying the needs in the market/mall (41\%), $21 \%$ did sport activities, and $23 \%$ others, involving gardening, going to a bank and visiting doctor.

Regarding the means of transportation used, $346(46.9 \%)$ of participants drive their private car. While others were private motorcycle 358 (48.5\%), online taxi (go car) 46 (6.2\%), train 17 (2.3\%) and bus 16 (2.5\%).

\section{Personal Hygiene Factors}

It has been observed that a positive behaviour has been implemented as a good personal hygiene practices at individual level (Table 3 ). There were $96.8 \%$ of participants wearing a mask when travelling outside or to another place. However, participants stated that sometimes they do not wear a mask (3.2\%). The majority of mask were cloth based, it was cited at $73 \%$ (Figure 3 ). Furthermore, with the objectives of protecting their families from the corona virus, almost $67.3 \%$ of respondents employed disinfectant at their house with 1-2 times of spraying in a month (Figure 4) and the antiseptic/sanitizer was brought during their activities (61\%). Also, 40\% of respondents declared to consume supplement during the pandemic (Figure 5)

\section{Table 3. Personal hygiene practices}




\begin{tabular}{|ll|}
\hline The use of Mask & $\mathbf{n}(\%)$ \\
\hline Yes & $746(96.8)$ \\
No & $25(3.2)$ \\
\hline The use of Disinfectant at Home & $\mathbf{n}(\%)$ \\
\hline Yes & $519(67.3)$ \\
No & $252(32.7)$ \\
\hline The use of Antiseptic/hand sanitizer & $\mathbf{n}(\%)$ \\
\hline Yes & $470(61)$ \\
No & $301(39)$ \\
\hline
\end{tabular}

Figure 6. depicts the frequency and duration in holding an object surface. The majority of participants hold a door handle and desk more than 6 times a day with 37.2\% and 28.1\% respectively. Additionally, the duration of handling that objects were 3 seconds (71.6\%) for former object and $>7$ second for latter object (37.9\%). Regarding the use of handphone, $42 \%$ of respondents reported using their handphone more than 6 hour in a day (Figure 7).

The frequent hand washing behaviour was shown on Figure 8 . The results showed that $8.2 \%$ of participants did hand washing at least once in a day and maximum of $>6 \mathrm{x}$ times (35.5\%of respondents) after going to toilet. Also, $38.5 \%$ of participants practised hand washing for 3 times/day prior eating and approximately about $23 \%$ did it every return to home for 1-2 times a day. While it was also reported that $27 \%$ of participants did this personal hygiene implementation for $>6$ times in every touching and object. Figure 9 . depicts the percentage of touching face among participated study. At least the respondents touched their part of face once in an hour, it was cited at 39\% (hair), $53.2 \%$ (forehead), $57.2 \%$ (neck), 54.6\% (ears), 47\% (eyes), 51.4\% (mouth), 53.7\% (chin), and 47.3\% and 43.8\% for cheek and nose respectively.

Regarding the source information related to COVID-19 update, the government website of COVID19.GO.ID was the most media (64\%) used by respondents, while the other platforms such as WhatsApp, Instagram, Facebook and Twitter was cited at $56 \%, 38 \%, 25 \%$ and $15 \%$ each. An active figure or influencer that encourage participants to apply COVID-19 prevention was also observed, at least more than one responses was obtained. $43.4 \%$ of their parents was being the main role, $41.9 \%$ was the government, and $32.3 \%$ was the relative.

\section{The Perception of COVID-19}

In this survey 388 (50\%) respondents thought that they understood the hazard and risk of COVID-19 derived from various resources, and 404 (52\%) thought that they could classified the risky groups that need to be monitored regarding coronavirus disease (Table 4). Additionally, The participants applied the ethics of coughs and sneeze in avoiding the spread of droplet by covering with the hand or elbows, with strongly agree 362 (47\%). Similarly, it can be seen that the participants was strongly agree in implementing social/physical distancing with 366 responses (48\%). An average in the context of carrying a hand sanitizer, 354 (46\%) respondents reported that they brought this item. Participants said that they changed immediately the clothes and soaked them with detergents when returned home with strongly agree of 339 (44\%) and agree of 260 (33\%). In contrast, 219 (28\%) respondents disagree that they take a shower using warm water after returning home and only 238 (31\%) respondents did not use special treatment on footwear 238 (31\%). Furthermore, 
$247(32 \%)$ respondent did a special treatment in packages or items using disinfectant acquired from online shopping or postman.

Table 4. The risk perception of COVID-19

\begin{tabular}{|c|c|c|c|c|c|c|}
\hline & & $\begin{array}{l}\text { Strongly } \\
\text { Disagree }\end{array}$ & Disagree & Neutral & Agree & $\begin{array}{l}\text { Strongly } \\
\text { Agree }\end{array}$ \\
\hline & & \multicolumn{5}{|c|}{$\mathrm{n}(\%)$} \\
\hline 1. & $\begin{array}{l}\text { I understand that hazards and risks of COVID-19 } \\
\text { from various resources }\end{array}$ & $8(1)$ & $17(2)$ & $62(8)$ & $\begin{array}{l}388 \\
(50)\end{array}$ & $\begin{array}{l}296 \\
(39)\end{array}$ \\
\hline 2. & $\begin{array}{l}\text { I understand the risk groups that need to be } \\
\text { monitored regarding Covid-19 disease }\end{array}$ & $8(1)$ & $14(2)$ & $60(8)$ & $\begin{array}{l}404 \\
(52)\end{array}$ & $\begin{array}{l}285 \\
(37)\end{array}$ \\
\hline 3. & $\begin{array}{l}\text { I apply the ethics of coughs and sneezes by } \\
\text { covering with hands or elbows }\end{array}$ & $50(6)$ & $39(5)$ & $28(4)$ & $\begin{array}{l}292 \\
(38)\end{array}$ & $\begin{array}{l}362 \\
(47)\end{array}$ \\
\hline 4. & $\begin{array}{l}\text { I really implement my distance position from other } \\
\text { people / physical distancing }\end{array}$ & $10(1)$ & $11(1)$ & $44(6)$ & $\begin{array}{l}340 \\
(44)\end{array}$ & $\begin{array}{l}366 \\
(48)\end{array}$ \\
\hline 5. & $\begin{array}{l}\text { I always carry a hand sanitizer with me wherever I } \\
\text { go }\end{array}$ & $34(4)$ & $63(8)$ & $82(11)$ & $\begin{array}{l}238 \\
(31)\end{array}$ & $\begin{array}{l}354 \\
(46)\end{array}$ \\
\hline 6. & $\begin{array}{l}\text { I changed immediately my clothes when I returned } \\
\text { home }\end{array}$ & $17(2)$ & $47(6)$ & $60(8)$ & $\begin{array}{l}308 \\
(40)\end{array}$ & $\begin{array}{l}339 \\
(44)\end{array}$ \\
\hline 7. & $\begin{array}{l}\text { I soak my clothes directly with detergent when } \\
\text { coming back home from outside }\end{array}$ & $58(7)$ & $97(12)$ & $\begin{array}{l}151 \\
(20)\end{array}$ & $\begin{array}{l}260 \\
(33)\end{array}$ & $\begin{array}{l}205 \\
(27)\end{array}$ \\
\hline 8. & $\begin{array}{l}\text { I always take a shower using warm water when } \\
\text { returning home from outside }\end{array}$ & $110(14)$ & $219(28)$ & $\begin{array}{l}150 \\
(20)\end{array}$ & $\begin{array}{l}179 \\
(23)\end{array}$ & $\begin{array}{l}113 \\
(15)\end{array}$ \\
\hline 9. & I use special treatment on footwear at home & $103(13)$ & $238(31)$ & $\begin{array}{l}196 \\
(25)\end{array}$ & $\begin{array}{l}153 \\
(20)\end{array}$ & $81(1)$ \\
\hline 10. & $\begin{array}{l}\text { I always spray packages / items using disinfectant } \\
\text { received from the postman }\end{array}$ & $41(5)$ & $105(14)$ & $\begin{array}{l}145 \\
(19)\end{array}$ & $\begin{array}{l}247 \\
(32)\end{array}$ & $\begin{array}{l}233 \\
(30)\end{array}$ \\
\hline
\end{tabular}

Table 5. Bivariate Analysis of sociodemographic characteristics associated with mass exodus and type of work 


\begin{tabular}{|c|c|c|c|c|c|}
\hline \multirow[t]{2}{*}{ No } & \multirow[t]{2}{*}{ Variable } & \multicolumn{2}{|c|}{ Take a trip to home town } & \multicolumn{2}{|l|}{ Type of Work } \\
\hline & & OR (95\% Cl) & P Value & OR $(95 \% \mathrm{Cl})$ & P Value \\
\hline \multirow[t]{3}{*}{1.} & Age & & & & \\
\hline & $>35$ years & $0.095(0.029-0.328)$ & 0.000 & $0.974(0.714-1.327)$ & 0.865 \\
\hline & $<=35$ years & & & & \\
\hline \multirow[t]{3}{*}{2.} & Gender & & & & \\
\hline & Male & $0.875(0.490-1.562)$ & 0.651 & $1.994(1.430-2.642)$ & 0.000 \\
\hline & Female & & & & \\
\hline \multirow[t]{3}{*}{3.} & Educational Background & & & & \\
\hline & Lower education & $1.089(0.450-2.638)$ & 0.851 & $0.675(0.395-1.091)$ & 0.096 \\
\hline & Higher education & & & & \\
\hline \multirow[t]{3}{*}{4.} & Occupational Status & & 0.180 & & \\
\hline & Unemployment & $1.513(0.834-2.748)$ & & $0.443(0.309-0.635)$ & 0.000 \\
\hline & Employment & & & & \\
\hline \multirow[t]{3}{*}{5.} & Major Islands & & 0.012 & & \\
\hline & Java & $0.467(0.260-0.837)$ & & $1.042(0.577-1.473)$ & 0.804 \\
\hline & Non-Java & & & & \\
\hline \multirow[t]{3}{*}{6.} & Domicile in JABODETABEK & & & & \\
\hline & Yes & $0.365(0.197-0.675)$ & 0.001 & $0.669(0.494-0.905)$ & 0.009 \\
\hline & No & & & & \\
\hline
\end{tabular}

The association of sociodemographic characteristics and participants who take a trip to home town and type of work are shown in Table 5. There was significant correlation between gender and type of work. The OR of male was 1.99 times more likely $(95 \% \mathrm{Cl}=1.430-2.642,, p<0.05)$ to work from office as opposed to female. Table 6 . illustrates the bivariate analysis between sociodemographic characteristics and personal hygiene. People aged over 35 years were 1.46 times less likely to practice hand washing compared to respondents who are under or equal to age of 35 years $(95 \% \mathrm{Cl}-1.097$ $1967, p<0.05)$. In addition, the male respondents were 2.06 times less likely to practice washing their hands after going to the toilets compared to women $(95 \% \mathrm{Cl}=1.543-2.760, p<0.05)$. Similar pattern was identified on doing hand-washing before eating and after touching an objects, male were 1.89 times and 1.749 times less likely to wash their hand as opposed to women $(95 \% \mathrm{Cl}=1.420-2.523, p<0.05)$ and $(95 \% \mathrm{Cl}=1.315-2.326, p<0.005)$ respectively. Our study also found that people with low education are 1.57 times less likely $(95 \% \mathrm{Cl}=1.008-2.458, p<0.05)$ to use antiseptics than people with higher education. Moreover, respondents with low education are 1.61 times more rarely to practice hand washing after going to the toilet compared to highly educated people $(95 \% \mathrm{Cl}=1.420-2.523, p<0.05)$.

Table 7. depicts the bivariate analysis of sociodemographic among study participants and touching object surfaces and face. Male participant were more likely to touch door handles and desks than women with estimated OR of 2.01 (95\% $\mathrm{Cl}$ $=1.509-2.678, p<0.05)$ and OR of $1.49(95 \% \mathrm{Cl}=1.119-2.009, p<0.05)$ each. Regarding face-touched behavior, Male had the opportunity to touch ears 1.68 times $(95 \% \mathrm{Cl}=1.247-2.283, p<0.05)$ and touch 1.38 times $(95 \% \mathrm{Cl}-1.022-1.862, p<$ 0.05) more often as opposed women. Further, study participants with low education tend to touch the part of face more 
often than those educational background with higher education, involving touching nose $(\mathrm{OR}=2.14,95 \% \mathrm{Cl}=1.366$ -

$3.355, p<0.05)$, cheek $(\mathrm{OR}=1.65,95 \% \mathrm{Cl}=1.058-2.584, p<0.05)$, chin $(\mathrm{OR}=1.69,95 \% \mathrm{Cl}=1.084-2.661, p<0.05)$, mouth $(\mathrm{OR}=1.61,95 \% \mathrm{Cl}=1.026-2.527, p<0.05)$, eyes $(\mathrm{OR}=1.70,95 \% \mathrm{Cl}=1.092-2.669, p<0.05)$, ears $(\mathrm{OR}=1.86,95 \% \mathrm{Cl}=$ $1.188-2.914, p<0.05)$, forehead $(\mathrm{OR}=2.16,95 \% \mathrm{Cl}=1.381-3.384, p<0.05)$, hair $(\mathrm{OR}=1.81,95 \% \mathrm{Cl}=1.152-2.848, p<$ $0.05)$, all $(\mathrm{OR}=2.19,95 \% \mathrm{Cl}=1.377-3.494, p<0.05)$.

Table 6. Bivariate Analysis of sociodemographic characteristic associated with positive behaviour of personal hygiene 


\begin{tabular}{|c|c|c|c|c|c|c|c|c|c|c|}
\hline & A & & B & & C & & D & & $E$ & \\
\hline & $\begin{array}{l}\text { OR } \\
\text { (95\% } \\
\text { Cl) }\end{array}$ & $\begin{array}{l}\mathrm{P} \\
\text { Value }\end{array}$ & $\begin{array}{l}\text { OR } \\
\text { (95\% } \\
\text { Cl) }\end{array}$ & $\begin{array}{l}\mathrm{P} \\
\text { Value }\end{array}$ & $\begin{array}{l}\text { OR } \\
\text { (95\% } \\
\text { Cl) }\end{array}$ & $\begin{array}{l}\mathrm{P} \\
\text { Value }\end{array}$ & $\begin{array}{l}\text { OR } \\
\text { (95\% } \\
\text { Cl) }\end{array}$ & $\begin{array}{l}\mathrm{P} \\
\text { Value }\end{array}$ & $\begin{array}{l}\text { OR } \\
(95 \% \\
\text { Cl) }\end{array}$ & $\begin{array}{l}\mathrm{P} \\
\text { Value }\end{array}$ \\
\hline Age & & & & & & & & & & \\
\hline$>35$ Years & 0.389 & 0.043 & 0.567 & 0.000 & 0.542 & 0.000 & 1.340 & 0.052 & 1.271 & 0.107 \\
\hline & $1.407)$ & & $\begin{array}{l}(0.411- \\
0.782)\end{array}$ & & $\begin{array}{l}(0.399- \\
0.736)\end{array}$ & & $\begin{array}{l}(0.097- \\
1.802)\end{array}$ & & $\begin{array}{l}(0.949- \\
1.704)\end{array}$ & \\
\hline$<=35$ Years & & & & & & & & & & \\
\hline Gender & & & & & & & & & & \\
\hline Male & 1.516 & 0.311 & 0.906 & 0.523 & 0.903 & 0.488 & 2.064 & 0.000 & 1.893 & 0.000 \\
\hline & $3.418)$ & & $\begin{array}{l}(0.671- \\
1.225)\end{array}$ & & $\begin{array}{l}(0.676- \\
1.206)\end{array}$ & & $\begin{array}{l}(1.543- \\
2.760)\end{array}$ & & $\begin{array}{l}(1.420- \\
2.523)\end{array}$ & \\
\hline Female & & & & & & & & & & \\
\hline Education & & & & & & & & & & \\
\hline Lower & 1.060 & 0.926 & 1.074 & 0.766 & 1.574 & 0.047 & 1.331 & 0.219 & 1.611 & 0.040 \\
\hline & $3.618)$ & & $\begin{array}{l}(0.672- \\
1.717)\end{array}$ & & $\begin{array}{l}(1.008- \\
2.458)\end{array}$ & & $\begin{array}{l}(0.840- \\
2.108)\end{array}$ & & $\begin{array}{l}(1.015- \\
2.559)\end{array}$ & \\
\hline $\begin{array}{l}\text { Higher } \\
\text { education }\end{array}$ & & & & & & & & & & \\
\hline $\begin{array}{l}\text { Occupational } \\
\text { Status }\end{array}$ & & & & & & & & & & \\
\hline Unemployment & 1.097 & 0.833 & 1.220 & 0.232 & 1.055 & 0.696 & 1.118 & 0.484 & 1.231 & 0.189 \\
\hline & $2.578)$ & & $\begin{array}{l}(0.882- \\
1.687)\end{array}$ & & $\begin{array}{l}(0.777- \\
1.458)\end{array}$ & & $\begin{array}{l}(0.818- \\
1.528)\end{array}$ & & $\begin{array}{l}(0.958- \\
1.680)\end{array}$ & \\
\hline Employment & & & & & & & & & & \\
\hline Main Islands & & & & & & & & & & \\
\hline Java & 0.768 & 0.538 & 0.933 & 0.675 & 0.822 & 0.221 & 1.099 & 0.552 & 1.071 & 0.663 \\
\hline & $1.763)$ & & $\begin{array}{l}(0.673- \\
1.292)\end{array}$ & & $\begin{array}{l}(0.601- \\
1.124)\end{array}$ & & $\begin{array}{l}(0.806- \\
1.498)\end{array}$ & & $\begin{array}{l}(0.787- \\
1.457)\end{array}$ & \\
\hline Non-Java & & & & & & & & & & \\
\hline $\begin{array}{l}\text { Domicile in } \\
\text { Jabodetabek }\end{array}$ & & & & & & & & & & \\
\hline Yes & 0.365 & 0.016 & 0.702 & 0.022 & 0.766 & 0.073 & 0.700 & 0.016 & 0.849 & 0.262 \\
\hline & $0.857)$ & & $\begin{array}{l}(0.519- \\
0.949)\end{array}$ & & $\begin{array}{l}(0.573- \\
1.025)\end{array}$ & & $\begin{array}{l}(0.524- \\
0.935)\end{array}$ & & $\begin{array}{l}(0.638- \\
1.130)\end{array}$ & \\
\hline No & & & & & & & & & & \\
\hline
\end{tabular}



A. The use of masker.
* $P<0.05$ significant correlation
B. The use of Disinfectant
C. The use of Hand Sanitizer/antiseptic
D. Handwashing after going toilet
E. Handwashing before eating

Table 6. Bivariate Analysis of sociodemographic characteristic associated with positive behaviour of personal hygiene (continued) 


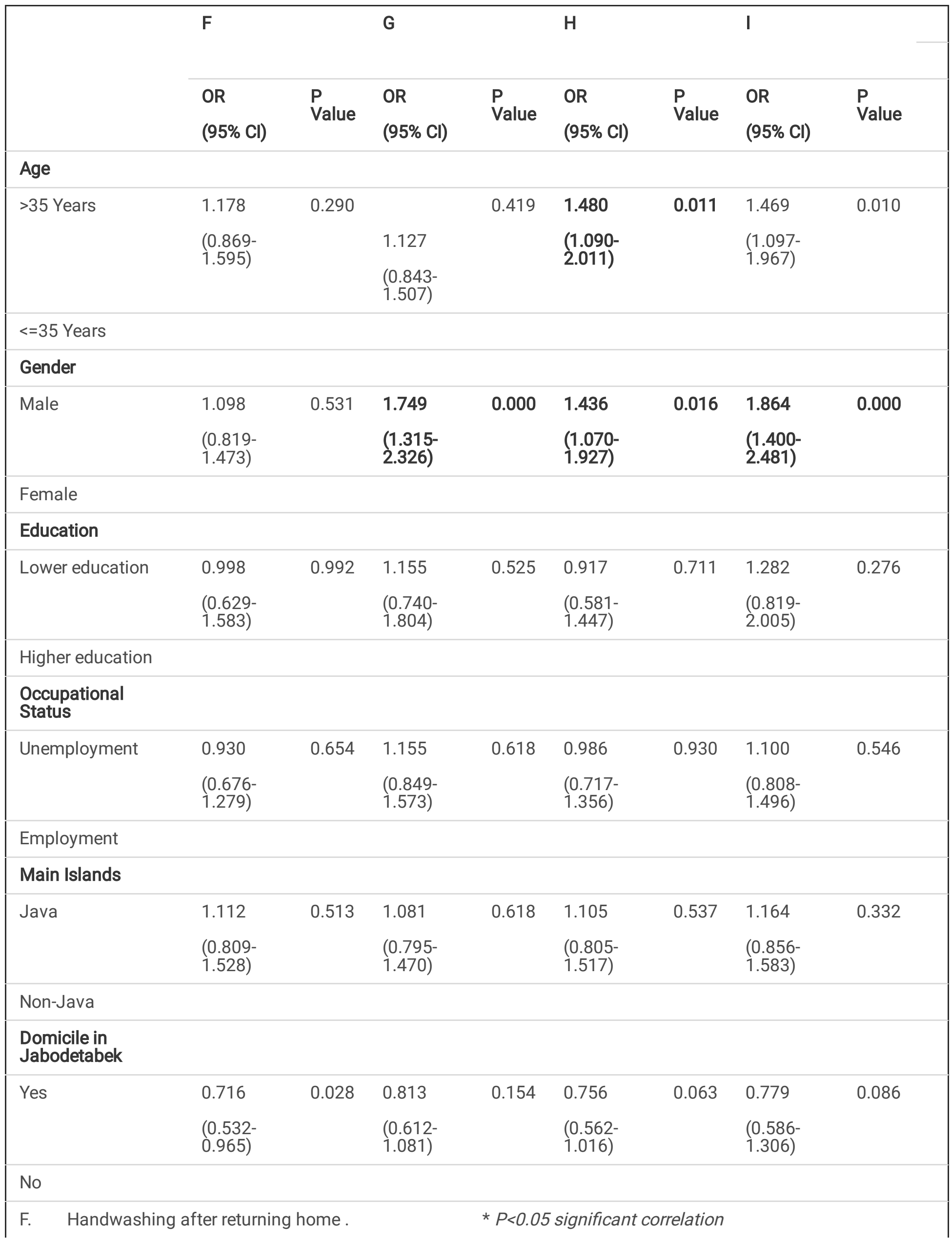



G. Handwashing every touching face
H. Handwashing others
I. Overall handwashing

Table 7. Bivariate Analysis of sociodemographic characteristic associated with touching objects and face touched 


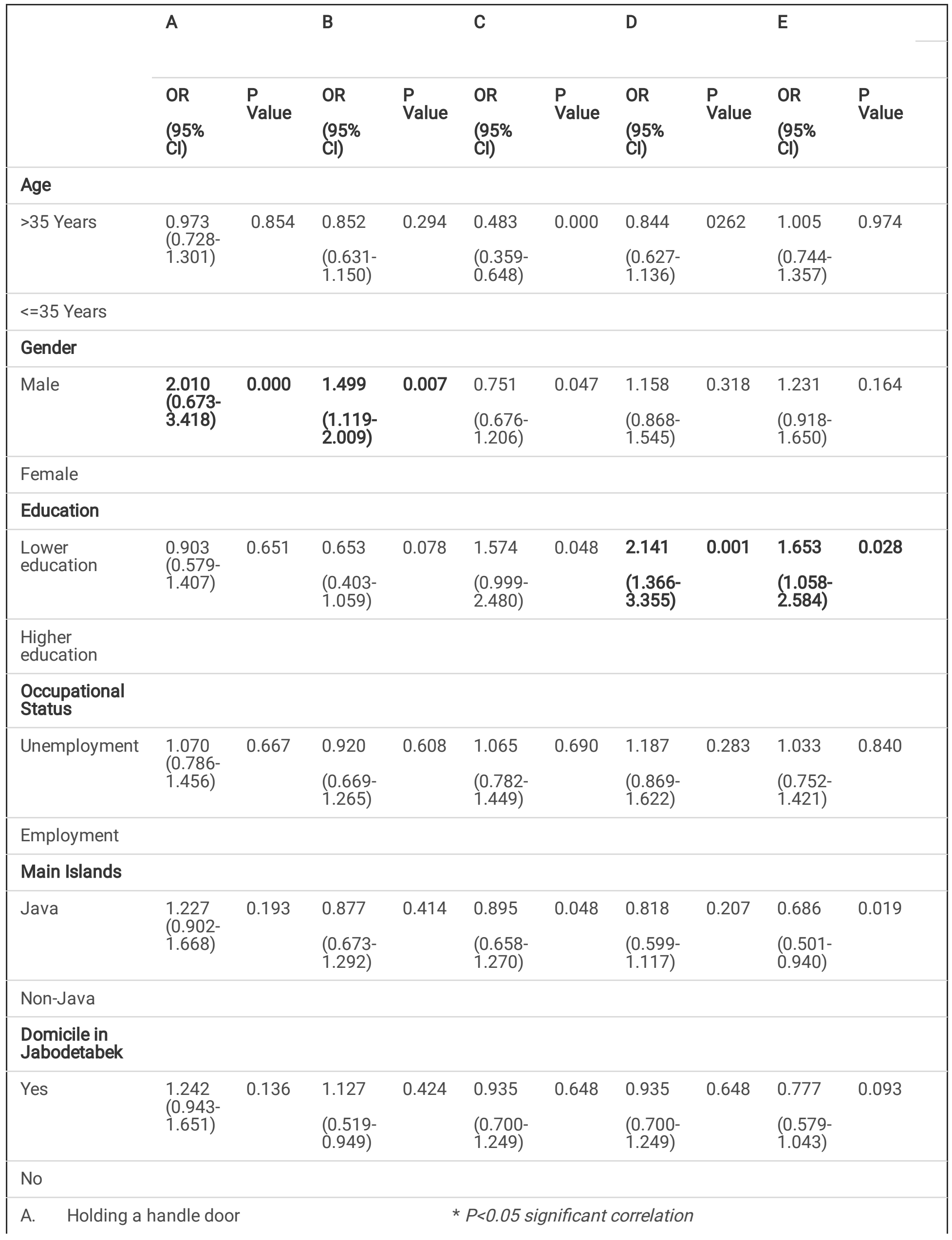



B. Holding a desk
C. The use of handphone
D. Touching nose
E. Touching cheek

Table 7. Bivariate Analysis of sociodemographic characteristic associated with touching objects and face touched (continued) 


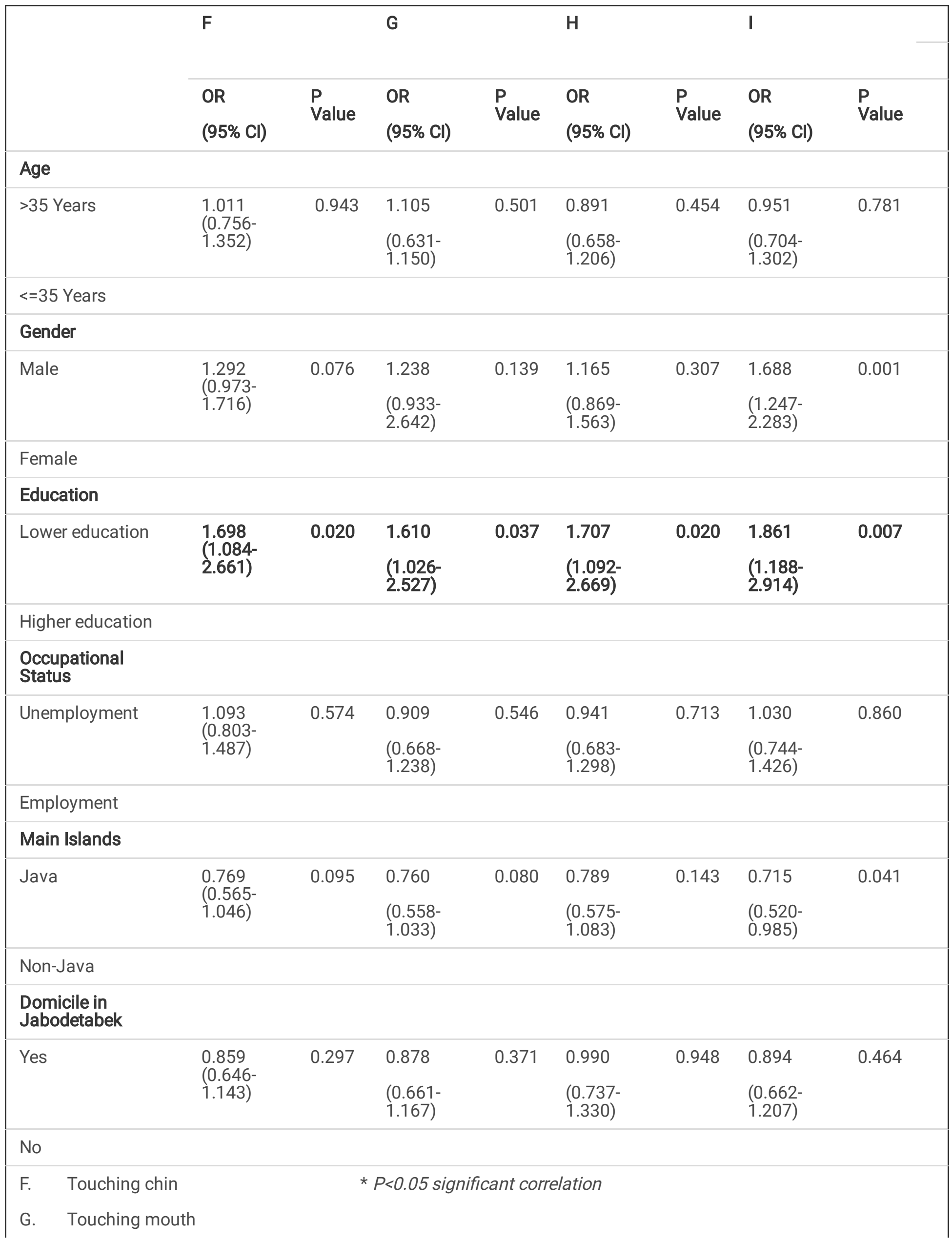


H. Touching eyes

I. Touching ears

Table 7. Bivariate Analysis of sociodemographic characteristic associated with objects and face touched (continued) 


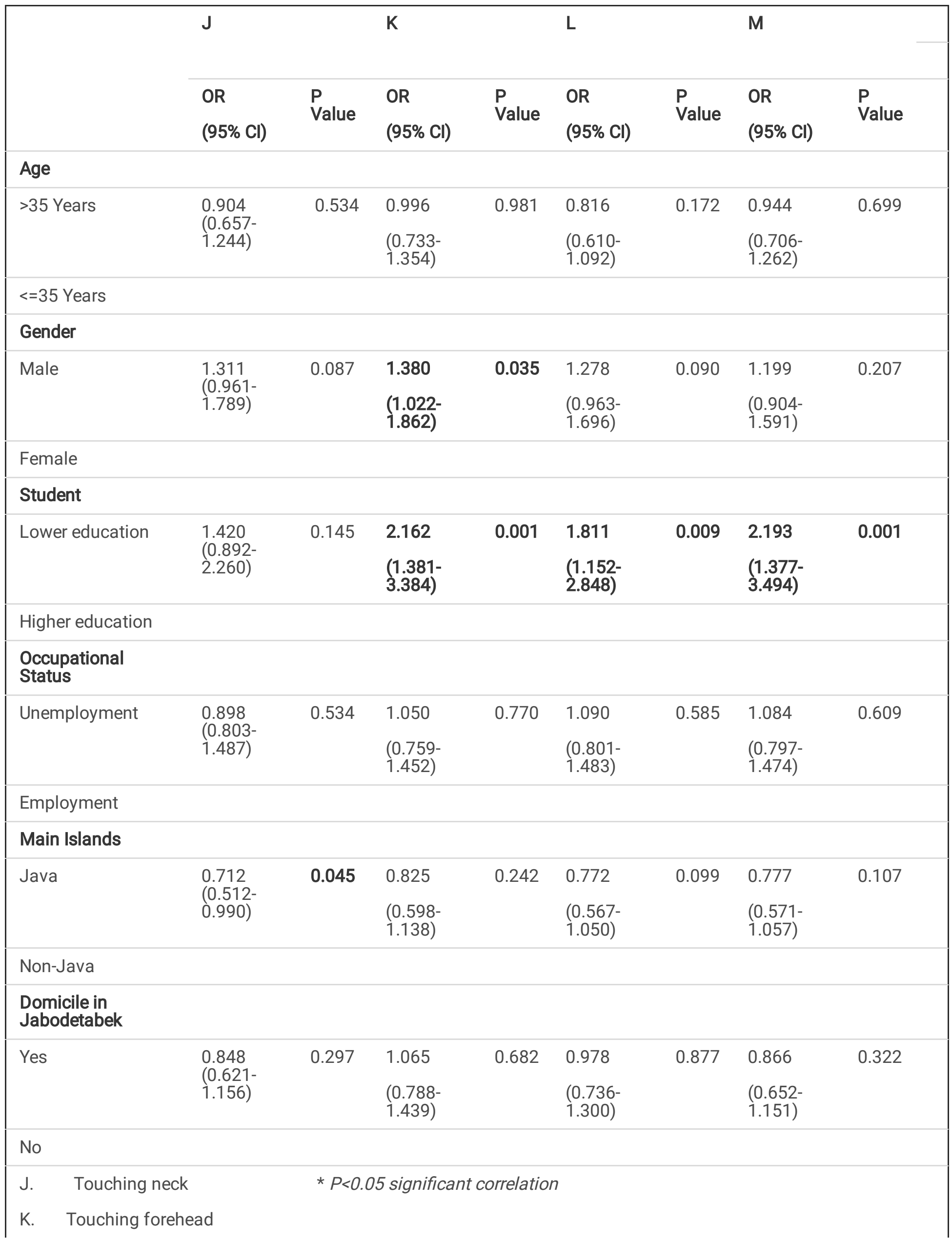




\section{Discussion}

Since the president of Indonesia declared the first two cases of COVID-19 on 2 March, the responses have been discussed such as the formation of operational Taskforce, known the National Board for Disaster Management (BNPB) on $13 \mathrm{March}^{16}$. Several national regulations have been set up at different levels from the president and ministerial level during the period of January until March $2020^{10}$. The first case was originated from Depok, West Java that had close contact with foreigners. Patient with positive COVID-19 then continued to grow in the number of areas, with the epicentre in DKI Jakarta as capital city of Indonesia ${ }^{17}$. Regarding the map of areas, the location of Jakarta, Bogor, Depok, Tangerang, and Bekasi are nearby location where these area were categorized as red zone. The Regulation No. 9 the Year 2020 has been set up under Ministry of Health related to the implementation of Large Scale Social Restrictions (Pembatasan Sosial Berskala Besar/PSBB), involving workplace and schools closures, religious and mass gatherings, physical distancing, and activities in public facilities ${ }^{18}$. Having said that, a basic principle of personal hygiene requires to be implemented in order to minimize the risk of COVID-19 transmission such as avoiding close contact with people from coronavirus infection, wearing mask and cough and sneezes with tissues or clothing as well as frequent handwashing ${ }^{19}$.

This cross sectional survey on 771 respondents found that the majority of the Indonesian community have been practiced good personal hygiene behaviour on their daily life towards the prevention to COVID-19 transmissions. Several best personal hygiene factors that reduce the transmission of COVID-19 have been implemented including the majority of the participants choose not to take travel to home town during the long holiday. Indeed, the participants knows that someone with frequent travelling, will increase the risk of coronavirus exposure ${ }^{20}$. This result is consistent with the findings from previous studies that reduced people mobility will reduce the transmission of COVID-19 21,22. It is indicated that the massive and aggressive health education performed by the government of Indonesia has been received well by the communities, especially the education and information shared daily by the Indonesian COVID-19 taskforce in collaboration with media pool press release.

Working from home policy has been effectively implemented since March 2020 after the pandemic declaration by the Indonesian President. Activities in the workplace has also being affected since the employees have to work from home. This research indicates that $67.3 \%$ of Indonesian people are performing their job remotely from home or work from home. International Labour Organization estimates that approximately $7.9 \%$ (260 million workers) of the world's workforce worked from home. Even though working from home can cause the decrease of physical activity and increase to high-risk exposure to screen exposure, which affect the sleep deficiencies ${ }^{23}$, yet this typical work is one of means to further physical distancing and strategy for mitigation in unemployment and keeping the dwellers safe ${ }^{24}$. Moreover, The quarantine, involving stay at home can effectively minimize the peak of pandemic as well as contribute in decrease the number of case by $25 \%{ }^{25}$. However, outdoor activities can be found in the society such as shopping a grocery in the market or mall. At the beginning, the government has implemented a regulation of large social restriction, a part of enterprises and stores that provides a basic community's consumption. In managing covid-19 prevention in this sector, the Ministry of Trade has set up a circular instruction No. 12 of 2020 regarding the recovery of trading activities carried out during the pandemic coronavirus disease 2019 and new normal. When the communities want to fulfil household need, even for those who cannot work from home, the way how communities travel by using a means of transportation is very important. Our findings identified that the majority of participant preferred to drive using their private care (46.9\%) or motorcycle (48.5\%). Yet, it also has identified for those who took a public transportation such as online taxi, bus and commuter line rail. Transportation is being a concerned in the transmission of COVID-19. In addition, public transportation have an important role in the spread of COVID-19, particularly the risk in accordance with the connectivity, 
distance and destination ${ }^{26}$. In Indonesian context, a Minister of Transportation Regulation No. 18 of 2020 on Transportation Control to Prevent the spread of Coronavirus has been issued on 9 April 2020. One of the rules is the use of private and public motor cycle, involving application-based motorcycle taxi. It has implemented with strict requirement due to of PSBB by consideration of health protocol in preventing COVID-19 transmission 27 .

It is strongly advised in the emergence of the coronavirus to implement the health protocol and a strict self-protection. Personal Protection Equipment (PPE) is one of hierarchy control that can be applied to eradicate COVID-1928. Furthermore, the previous study reported that coronavirus might spread through aerosols from respiratory droplets ${ }^{29}$. The common protection used for respiratory infections such as novel coronavirus are masks and respirators with different indication for healthcare employees, illness patients and societies ${ }^{30}$. The masks are also worn to forbid pathogens entering respiratory tract by cutting the droplet transmission path directly ${ }^{31}$. Our findings show that $96.8 \%$ of respondents worn the masks during their activities. This mask-wearing rates was similar finding with the study conducted in Japan with $99.4 \%$, while in the South Korea was cited at $85.5 \% 32$. As far as types of masks used, cloth masks were the most dominant masks that worn by individuals (73\%), while surgical masks and N95 also identified at $22 \%$ and $3 \%$ respectively. In fact, it has been undebatable for the effectiveness of cloth masks as there are a few research conducted on it. Some research finding shows that cloth masks caused a higher rates of infection as opposed to medical masks. Hence, it is not recommended for health workers ${ }^{33}$. In addition, cloth masks may rise the infection risk due to its physical properties such us reuse, frequency and effectiveness of washing up, and moisture ${ }^{34}$. The study showed that cloth masks had a higher penetration of particles as opposed to medical masks, it was cited at $97 \%$ and $44 \%$ respectively. Based on this study, the cloth mask have potential to cause illness much higher than medical masks ${ }^{34}$. On the other hand, cloth mask can reduce the virus particles into the air when people have an conversation, sneezes or coughs. It also can minimize the spread of COVID-1935. According to Adelayanti ${ }^{36}$, cloth mask can be worn as last alternative in protecting from the spread of COVID-19 on human, particularly in crisis situation. Hence, at the population level, the use of masks, is very important to minimize the exposure to droplets, aerosol and particle and spread the infection to others ${ }^{37}$.

The use of disinfectant in handling COVID-19 was also familiar in Indonesia. $67.7 \%$ of respondents did a disinfectant spraying for at least once in a month with chlorine-based products. Environmental surface are likely possible to be contaminated with SARS-CoV-2, both in health care and non-health care settings such as walls, chairs, electronic equipment's, and tables. Hence, these surfaces must be disinfected in preventing and controlling the hazard and risks of transmission $^{38}$. Furthermore, the transmission has been associated between individuals and contacts with surface in the environment ${ }^{39}$. In fact, since disinfectant has detrimental effects such as irritation and/or allergens ${ }^{40}$. Hence, the safety operation should be considered such as wearing PPE during the use of disinfectant in order to minimise the risk of infection on human body ${ }^{41}$. It has been obtained in the current study that the respondents did a treatment on packages/ or items using disinfectant received from postman as infection prevention during the pandemic situation.

Another crucial strategy for communities in prevention of the risk of COVID-19 is the use of portable hand sanitizer. The majority of participants (61\%) brought this item to protect the virus transmission. The hand sanitizer or antiseptic hand sanitisation, is known as antiseptic hand rubs which contains alcohol based. It is used as one of protection in minimizing the transmission of infection among communities as well as health professionals ${ }^{42}$. In addition, this item usually is effective and helpful in situation where the hand washing facilities are not available in public places or at work.

Several studies have shown that COVID-19 exists and persistent on various surfaces. Chin et al. ${ }^{43}$ reported that the novel coronavirus can survive up to 1 day on wood and cloth, 2 and 4 days on glass and stainless steel and plastic respectively. Van Doremalen et al. ${ }^{44}$ also pointed out that this virus remained stay up to 4 hours on copper and 24 hours 
on carboard. For this reason, societies have a potential risk for exposure to the virus. Our findings reveal that the majority of respondents hold a door handle and a desk for at least more than six times for three to seven seconds in a day. In fact, the use of mobile phone was massively frequent with average more than six hours in a day. While the COVID-19 is present on different surface, it is possible to being infected by touching that surface, involving door handles, mobile phones, and public transport handholds, and subsequently transmitted to body through our hand, mouth, nose or eyes ${ }^{45}$.

The finding on our study found that male are less likely to perform better hand hygiene as opposed to female. In addition, participants with low education tend to touch the part of face often than those who had higher education. The previous study reported that girls tend to have a frequent best practise in handwashing behavior, and educational background with higher education reported to practice better behavior on personal hygiene ${ }^{31}$. Our Study also found that $38.5 \%$ of subject respondents did hand washing for three times before eating. Almost $23.2 \%$ of respondents declared hand washing for twice per day in every return home. Moreover, $35.5 \%$ and $27 \%$ of respondents declared hand washing for six times after going the toilet and every touching an object each. The polish study showed that it has been indicated that approximately $40 \%$ of respondents did hand washing after handshaking, while this basic hygiene behaviours also indicated in the subject studies doing hand wand washing after touching their part of bodies such as nose (39\%), sneezing (44\%), and coughing (40\%) ${ }^{46}$.

This study is an early detection to obtain an overview of positive behaviour of personal hygiene for the prevention and control towards COVID-19 among dwellers in Indonesia. It contributes to deliver an information and give better understanding regarding on how communities can support the government in handling the pandemic situation. This study, however, has several limitations. First, the sample size is limited. Second, online questionnaire may not reflects the real situation of the communities. Third, the study was conducted during the Large Scale Social Restrictions which may not reflect the real situation during the released of Large Scale Social Restrictions where public may have a varied activities while they may no longer implement positive behaviour of personal hygiene. Further studies are needed to explore whether the positive behaviour may reduce or change after the release of Large Scale Social Restrictions. Fourth, the majority of respondents were coming from the Java Island, while the representativeness of the population might not be covered, and this might be a bias factor. The last, the data was administrated in bivariate analysis, hence multivariate analysis is needed for further analysis.

\section{Conclusions}

Pandemic COVID-19 has a huge impacts on societies around the world, including Indonesia. The community has an integral part in taking action to prevent the spread of transmission as well as to minimize the impact of outbreak and controlling the diseases. The most crucial strategy for the population is practising positive behaviour of better personal hygiene such as frequently hand-washing, wearing masks, use hand sanitizer if the hand-washing facilities is not available, avoid face-touching, avoid crowds and avoid close contact with individual. The positive behaviour of personal hygiene need to be maintain during the pandemic in order to controlled the COVID-19 spreads. There should be a good role model

\section{Abbreviations}

COVID-19 (Coronavirus Disease-2019)

Jabodetabek (Jakarta, Bogor, Depok, Tangerang, Bekasi)

PHEIC (Public Health Emergency of International Concern)

PPE (Personal Protective Equipment)

Page 22/33 
WHO (World Health Organization)

\section{Declarations}

\section{Ethics approval and consent to participate}

The informed consent has been describe in details during the Ethics Approval and Consent before the study conducted, and has been approved under the Ethics Approval Letter from Ethics Committee Faculty of Public Health, Universitas Indonesia Number: Ket- 435/UN2.F10.D11/PPM.00.02/2020. Inform consent was obtained from respondents by agreeing and fulfil the terms condition to participate in the study. The researchers applied the informed consent during the study with the principle of beneficial, no harm, confidential, justice and voluntary participants. Hence, several information should be agreed by participants prior data collection. Particularly, if the participant under 18 years old, those have to ask permission to their parent or legal guardian. If it does not meet the criteria, the system automatically stops the survey.

\section{Consent for publication}

Not Applicable

\section{Availability of data and materials}

The dataset utilized and/or analysed during the present study are available on reasonable request from the corresponding author.

\section{Competing Interest}

The authors declare no conflict interest.

\section{Funding}

This study was supported by grants from Research and Community Engagement Directorate (DRPM) Universitas Indonesia under contract number: NKB 3966/UN2.RST/HKP.05.00/2020

\section{Authors' Contributions}

F.L designed the survey, provide direction on data collection, wrote the manuscript draft, A.K developed online questionnaire, collecting data and analysed data, and wrote the draft manuscript. M.I, F.A, G.R, F.S, G.H, A.H, RM, BW, YK assist during data collection and review the manuscript. All authors have reviewed and approved the manuscripts.

\section{Acknowledgments}

The authors would like to say thank you to Occupational Health and Safety Department, Faculty of Public Health, Universitas Indonesia, Disaster and Risk Reduction Center (DRRC) Universitas Indonesia, and Dewan K3 Nasional $(D K 3 N) / T h e$ National Safety \& Health Council of Indonesia and the co-authors who completed this study.

\section{References}

1. Huang C, Wang Y, Li X, Ren L, Zhao J, Hu Y, et al. Clinical features of patients infected with 2019 novel coronavirus in Wuhan, China. Lancet. 2020;395(10223):497-506. 
2. Wu YC, Chen CS, Chan YJ. The outbreak of COVID-19: An overview. J Chinese Med Assoc. 2020;83(3):217-20.

3. Ehrenberg JP, Zhou XN, Fontes G, Rocha EMM, Tanner M, Utzinger J. Strategies supporting the prevention and control of neglected tropical diseases during and beyond the COVID-19 pandemic. Infect Dis Poverty. 2020;9(1):1-7.

4. Liu J, Liao X, Qian S, Yuan J, Wang F, Liu Y, et al. Community Transmission of Severe Acute Respiratory. Emerg Infect Dis. 2020;26(6):1320-3.

5. Bender L. Guidance for COVID-19 Prevention and Control. IASC Inter-Agency Standing Comm. 2020;(March):1-13.

6. Topcuoglu N. Public Health Emergency of International Concern: Coronavirus Disease 2019 (COVID-19). Open Dent J. 2020;14(1):71-2.

7. Helmy YA, Fawzy M, Elaswad A, Sobieh A, Kenney SP, Shehata AA. The COVID-19 Pandemic: A Comprehensive Review of Taxonomy, Genetics, Epidemiology, Diagnosis, Treatment, and Control. J Clin Med. 2020;9(4):1225.

8. World Health Organization. Disease Situation Report. 2020;19:1-21.

9. go.id. COVID-19 Indonesia Situation Update. 2020. Available from: https://kemlu.go.id/osaka/en/news/5251/covid19-indonesia-situation-update

10. Djalante R, Lassa J, Setiamarga D, Sudjatma A, Indrawan M, Haryanto B, et al. Review and analysis of current responses to COVID-19 in Indonesia: Period of January to March 2020. Prog Disaster Sci. 2020;6:100091.

11. go.id. Peta Sebaran. 2020. Available form https://covid19.go.id/peta-sebaran

12. United Nation. Indonesia Multi-Sectoral Response Plan to COVID-19. Covid Mptf [Internet]. 2020;(May-October):164. Available from: https://reliefweb.int/report/indonesia/indonesia-multi-sectoral-response-plan-covid-19-mayoctober-2020

13. Yanti B, Wahyudi E, Wahiduddin W, Novika RGH, Arina YMD, Martani NS, et al. Community Knowledge, Attitudes, and Behavior Towards Social Distancing Policy As Prevention Transmission of Covid-19 in Indonesia. J Adm Kesehat Indones. 2020;8(2):4.

14. Sibony AL. The UK covid-19 response: A behavioural irony? Eur J Risk Regul. 2020;11(2):350-7.

15. Bavel JJV, Baicker K, Boggio PS, Capraro V, Cichocka A, Cikara M, et al. Using social and behavioural science to support COVID-19 pandemic response. Nat Hum Behav [Internet]. 2020;4(5):460-71. Available from:

http://dx.doi.org/10.1038/s41562-020-0884-z

16. MOORE PE. World Health Organization. Can Serv Med J. 1955;11(3):121-6.

17. Human Initiative. Situation Report \# 5 COVID-19 PANDEMIC Situation Report \# 5 COVID-19 PANDEMIC. 2020; (March).

18. Suraya I, Nurmansyah MI, Rachmawati E, Aufa B Al, Koire II. The Impact of Large-scale Social Restrictions on the Incidence of COVID-19: A Case Study of Four Provinces in Indonesia. 2020;(1):49-53.

19. Culp WC. Coronavirus Disease 2019. A A Pract. 2020;14(6):e01218.

20. Safrizal ZA, Danag IP, Safriza S, Bimo . Pedoman Umum Menghadapi Pandemi COVID-19 bagi Pemerintah Daerah. Kementerian dalam Negeri; 2020.

21. Badr H, Du H, Marshall M, Dong E, Squire M, Gardner L. Association between mobility patterns and COVID-19 transmission in the USA: a mathematical modelling study. The Lancet Infectious Diseases. 2020;20(11):1247-1254.

22. Zhou Y, Xu R, Hu D, Yue Y, Li Q, Xia J. Effects of human mobility restrictions on the spread of COVID-19 in Shenzhen, China: a modelling study using mobile phone data. Lancet Digit Health. 2020;2(8):e417-24.

23. Majumdar P, Biswas A, Sahu S. COVID-19 pandemic and lockdown: cause of sleep disruption, depression, somatic pain, and increased screen exposure of office workers and students of India. Chronobiol Int [Internet].

2020;00(00):1-10. Available from: https://doi.org/10.1080/07420528.2020.1786107

24. Mollona E, Aivazidou E, Barberio V, Cunico G, Pareschi L. Policy Brief Policy Brief. 2019;(April):14.

Page 24/33 
25. Rashid ; Ridda I; King C; Begun M; Tekin H; Wood JG; Booy R. Evidence compendium and advice on social distancing and other related measures for response to an influenza pandemic, Paediatric Respiratory Reviews. 2015; vol. 16, pp. 119 - 126, 10.1016/j.prrv.2014.01.003

26. Zheng R, Xu Y, Wang W, Ning G, Bi Y. Spatial transmission of COVID-19 via public and private transportation in China. Travel Med Infect Dis. 2020;34(April).

27. Cabinet Secretary of The Republic of Indonesia. Gov't Issues Regulations on Transportation Control to Prevent COVID-19 Spread. 2020. Available from https://setkab.go.id/en/govt-issues-regulation-on-transportation-control-toprevent-covid-19-spread/

28. Setiati S, Azwar MK. COVID-19 and Indonesia. Acta Med Indones. 2020;52(1):84-9.

29. Chu DK, Akl EA, Duda S, Solo K, Yaacoub S, Schünemann HJ, et al. Physical distancing, face masks, and eye protection to prevent person-to-person transmission of SARS-CoV-2 and COVID-19: a systematic review and metaanalysis. Lancet. 2020;1973-87.

30. Maclntyre CR, Chughtai AA. A rapid systematic review of the efficacy of face masks and respirators against coronaviruses and other respiratory transmissible viruses for the community, healthcare workers and sick patients. Int J Nurs Stud [Internet]. 2020;108:103629. Available from: https://doi.org/10.1016/j.jjnurstu.2020.103629

31. Chen X, Ran L, Liu Q, Hu Q, Du X, Tan X. Hand hygiene, mask-wearing behaviors and its associated factors during the COVID-19 epidemic: A cross-sectional study among primary school students in Wuhan, China. Int J Environ Res Public Health. 2020;17(8).

32. Chen Y-J, Qin G, Chen J, Xu J-L, Feng D-Y, Wu X-Y, et al. Comparison of Face-Touching Behaviors Before and During the Coronavirus Disease 2019 Pandemic. JAMA Netw open [Internet]. 2020;3(7):e2016924. Available from: http://www.ncbi.nlm.nih.gov/pubmed/32725247

33. Mahase E. Covid-19: What is the evidence for cloth masks? BMJ [Internet]. 2020;369(April):m1422. Available from: http://dx.doi.org/doi:10.1136/bmj.m1422

34. Szarpak L, Smereka J, Filipiak KJ, Ladny JR, Jaguszewski M. Cloth masks versus medical masks for COVID-19 protection. Cardiol J. 2020;27(2):218-9.

35. The Washington State Department of Health. Guidance on Cloth Face Coverings from the Washington State Department of Health. 2020;

36. Adelayanti N. Cloth Masks Have Low Effectiveness to Prevent COVID-19. 2020;(April).

37. Javid B, Weekes MP, Matheson NJ. Covid-19: should the public wear face masks? BMJ [Internet]. 2020;369(April):11-2. Available from: http://dx.doi.org/doi:10.1136/bmj.m1442

38. Organization WH. Advice on the use of masks in the context of COVID-19: interim guidance-2. Guía Interna la OMS [Internet]. 2020;(April):1-5. Available from: https://www.who.int/docs/default-

39. Organization WH. Report of the WHO-China Joint Mission on Coronavirus Disease 2019 (COVID-19). WHO-China Jt Mission Coronavirus Dis 2019 [Internet]. 2020;1(February):40. Available from: https://www.who.int/docs/defaultsource/coronaviruse/who-china-joint-mission-on-covid-19-final-report.pdf

40. Goh CF, Ming LC, Wong LC. Dermatologic reactions to disinfectant use during the COVID-19 pandemic. Clin Dermatol [Internet]. 2020; Available from: https://doi.org/10.1016/j.clindermatol.2020.09.005

41. Takagi G, Yagishita K. Principles of Disinfectant Use and Safety Operation in Medical Facilities During Coronavirus Disease 2019 (COVID-19) Outbreak. SN Compr Clin Med. 2020;2(8):1041-4.

42. Gold NA, Mirza TM, Avva U. Alcohol Sanitizer . In: StatPearls . Treasure Island (FL): StatPearls Publishing; 2020. . Available from: https://www.ncbi.nlm.nih.gov/books/NBK513254/

43. Chin, A.W.H., Chu, J.T.S., Perera, M.R.A., Hui, K.P.Y., Yen, H.-L., Chan, M.C.W., et al.,. Stability of SARS-CoV- 2 in different environmental conditions. The Lancet Microbe S2666524720300033.2020.

Page 25/33 
https://doi.org/10.1016/S2666- 5247(20)30003-3

44. van Doremalen, N., Bushmaker, T., Morris, D.H., Holbrook, M.G., Gamble, A., Williamson, B.N., et al.. Aerosol and Surface Stability of SARS-CoV-2 as Compared with SARS-CoV-1. N Engl J Med. 2020; 382, 1564-1567. https://doi.org/10.1056/NEJMc2004973

45. Fiorillo L, Cervino G, Matarese M, D'amico C, Surace G, Paduano V, et al. COVID-19 surface persistence: A recent data summary and its importance for medical and dental settings. Int J Environ Res Public Health. 2020;17(9).

46. Głabska D, Skolmowska D, Guzek D. Population-based study of the influence of the COVID-19 pandemic on hand hygiene behaviors-polish adolescents' COVID-19 experience (place-19) study. Sustain. 2020;12(12).

\section{Figures}

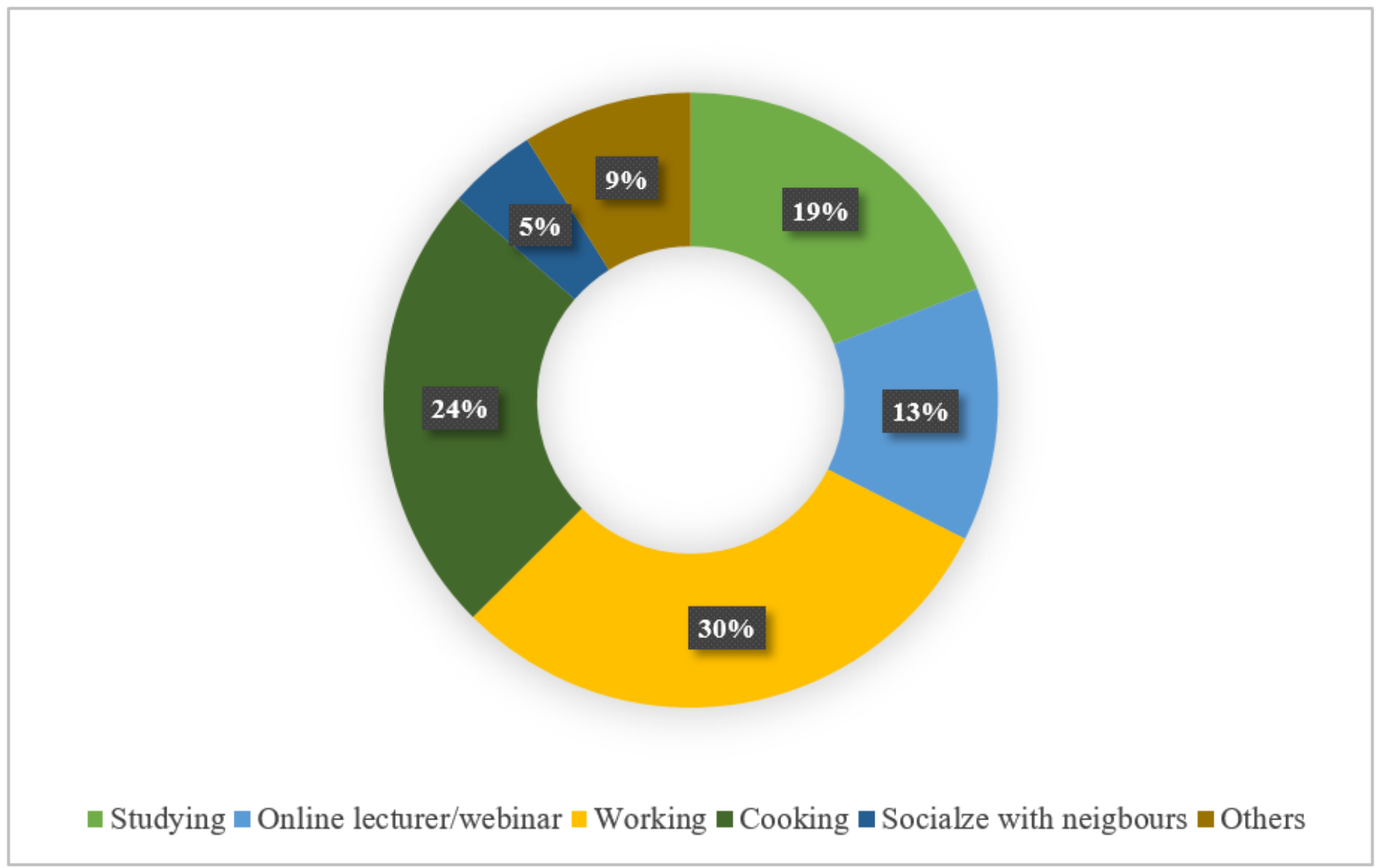

Figure 1

Indoor Activities during Pandemic COVID-19 


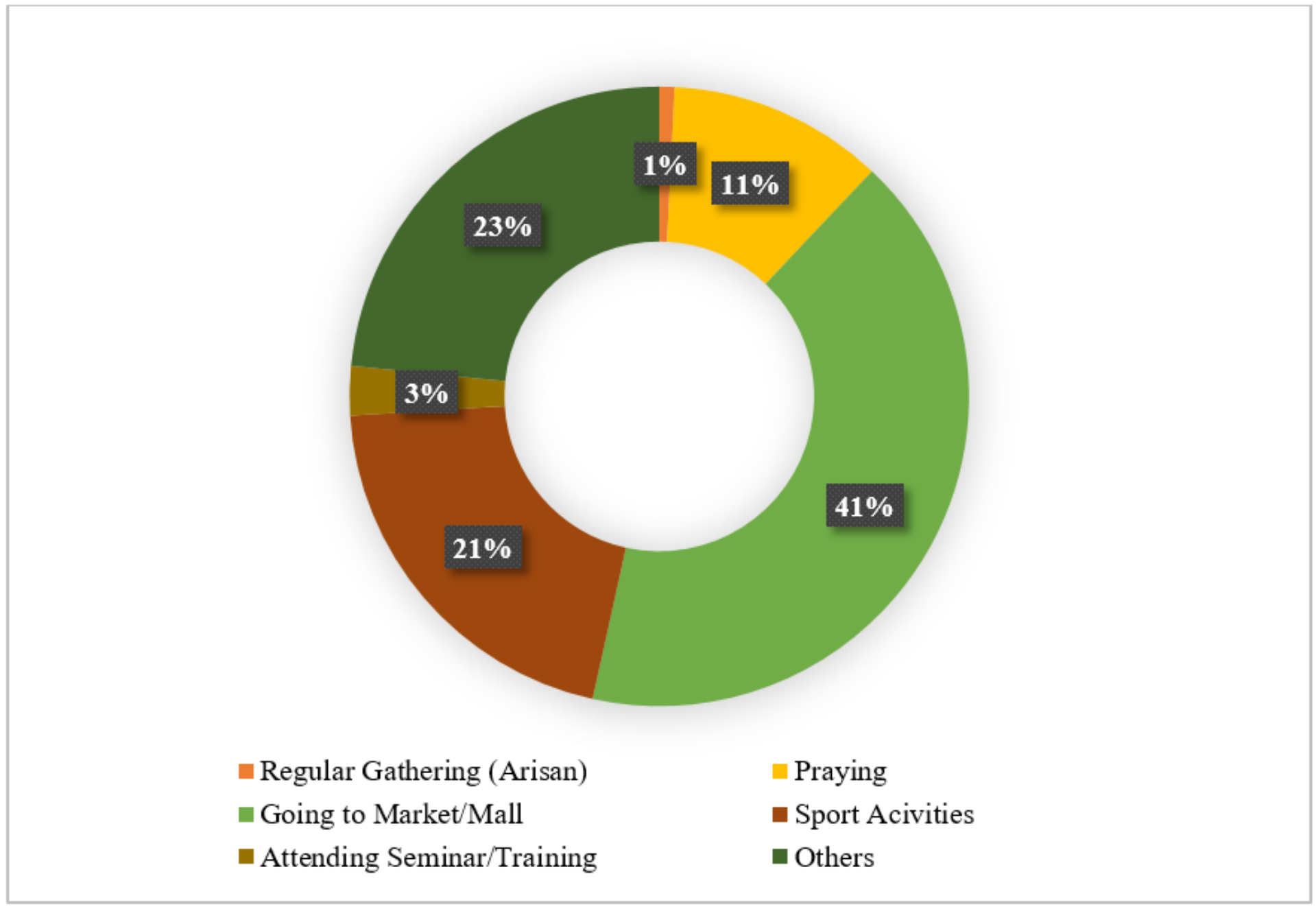

\section{Figure 2}

Activities outside during Pandemic COVID-19 


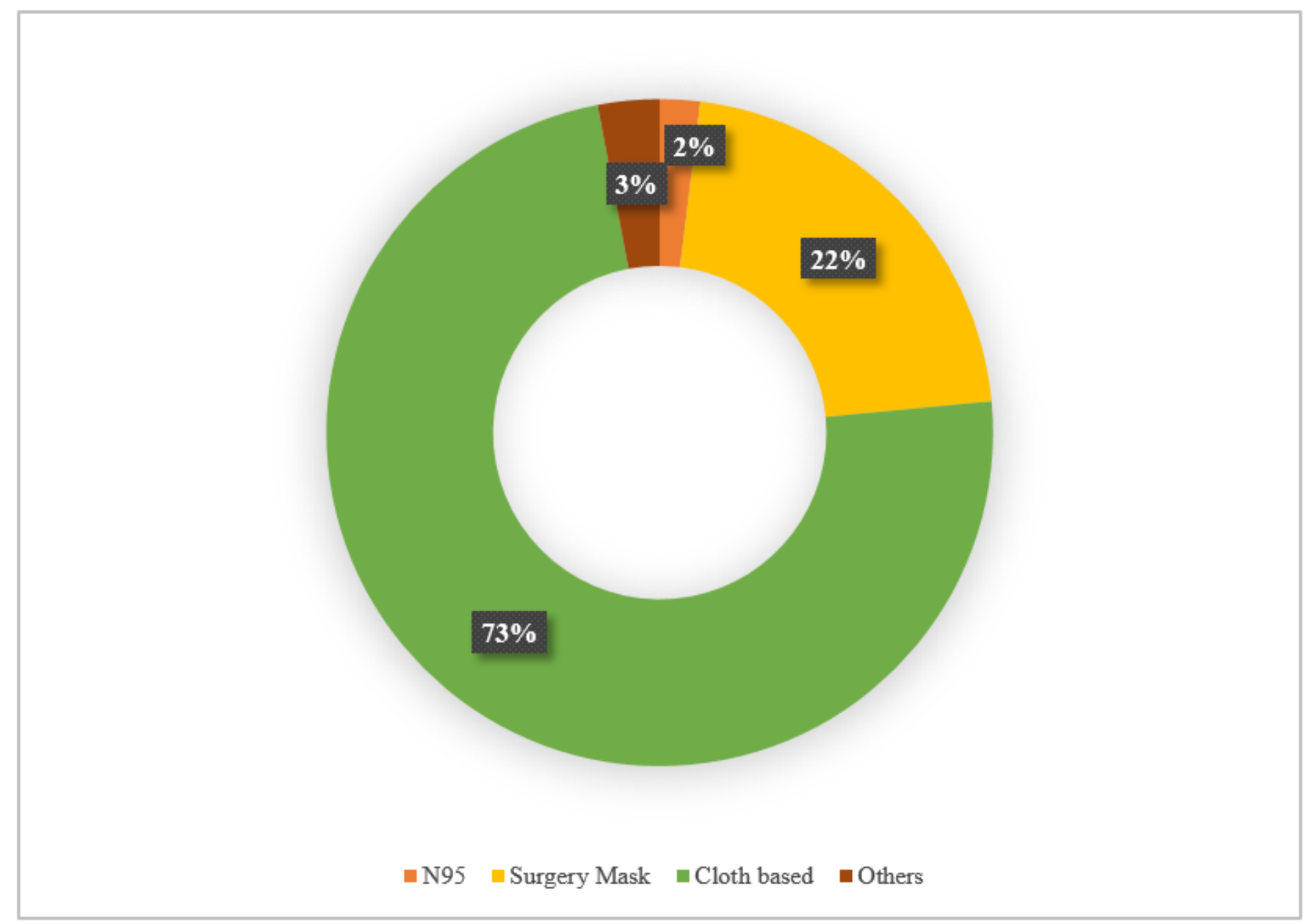

Figure 3

Types of Mask Used 


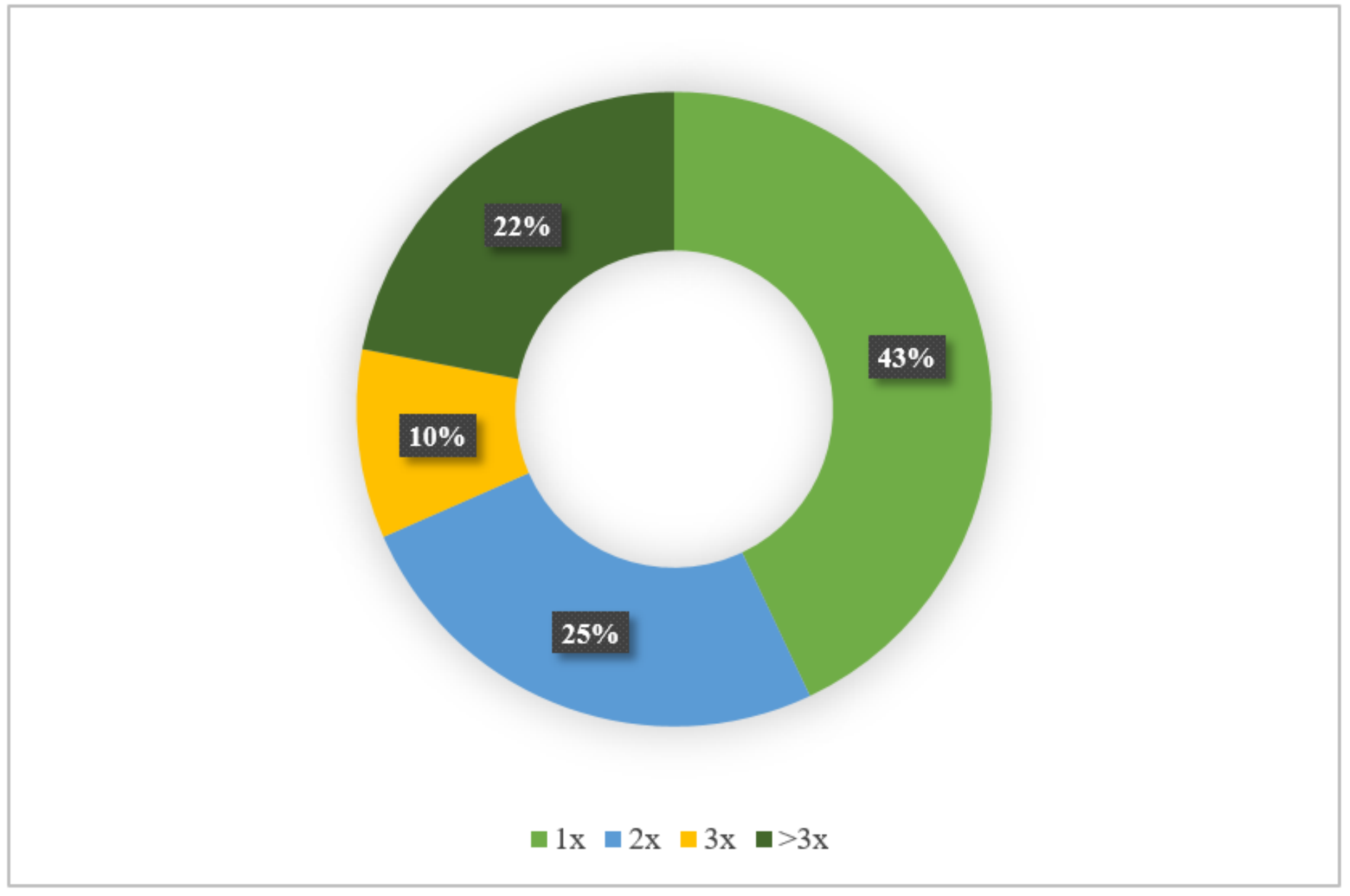

Figure 4

Frequency of disinfectant spraying (per month) 


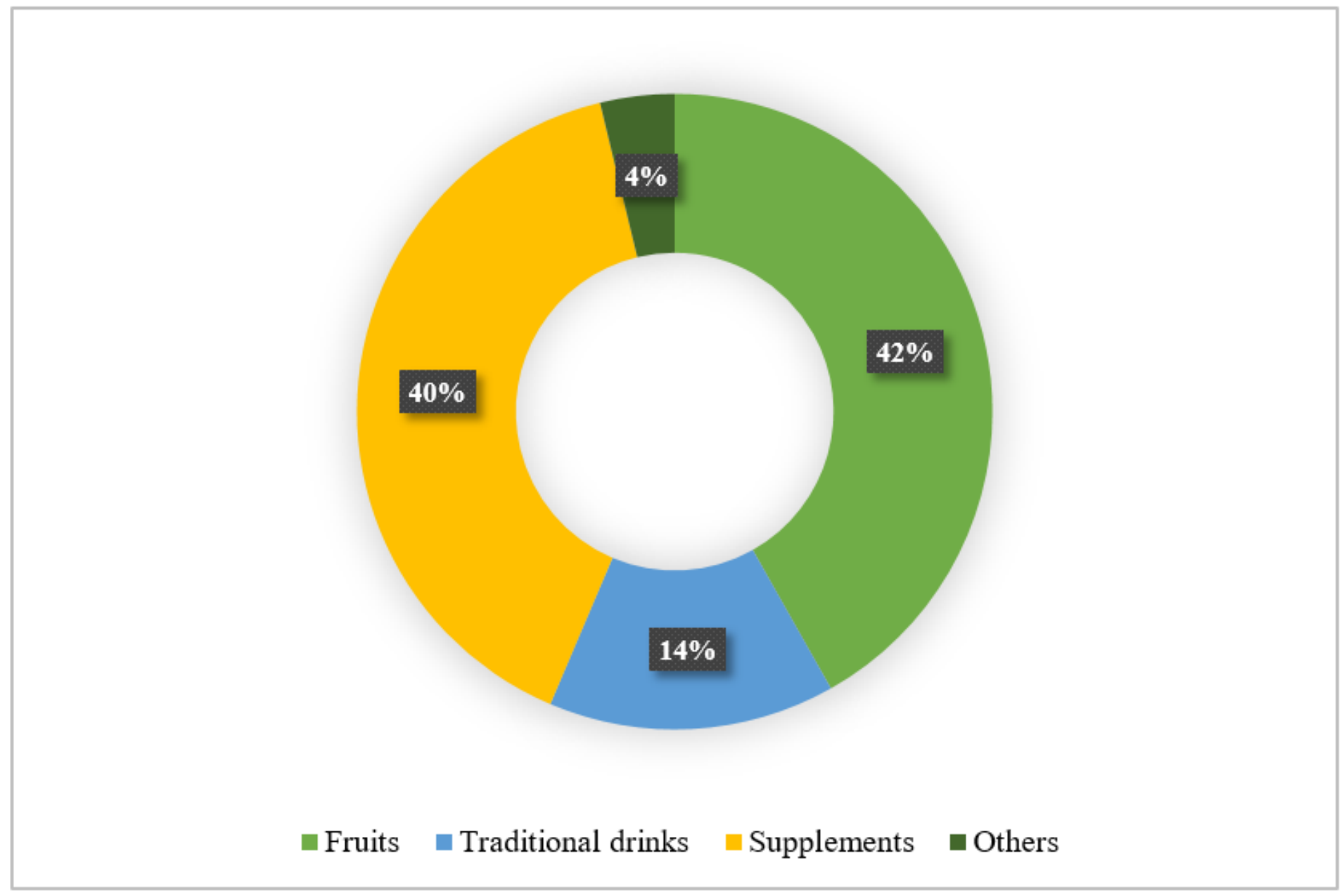

Figure 5

The consumption of Vitamin and Supplements

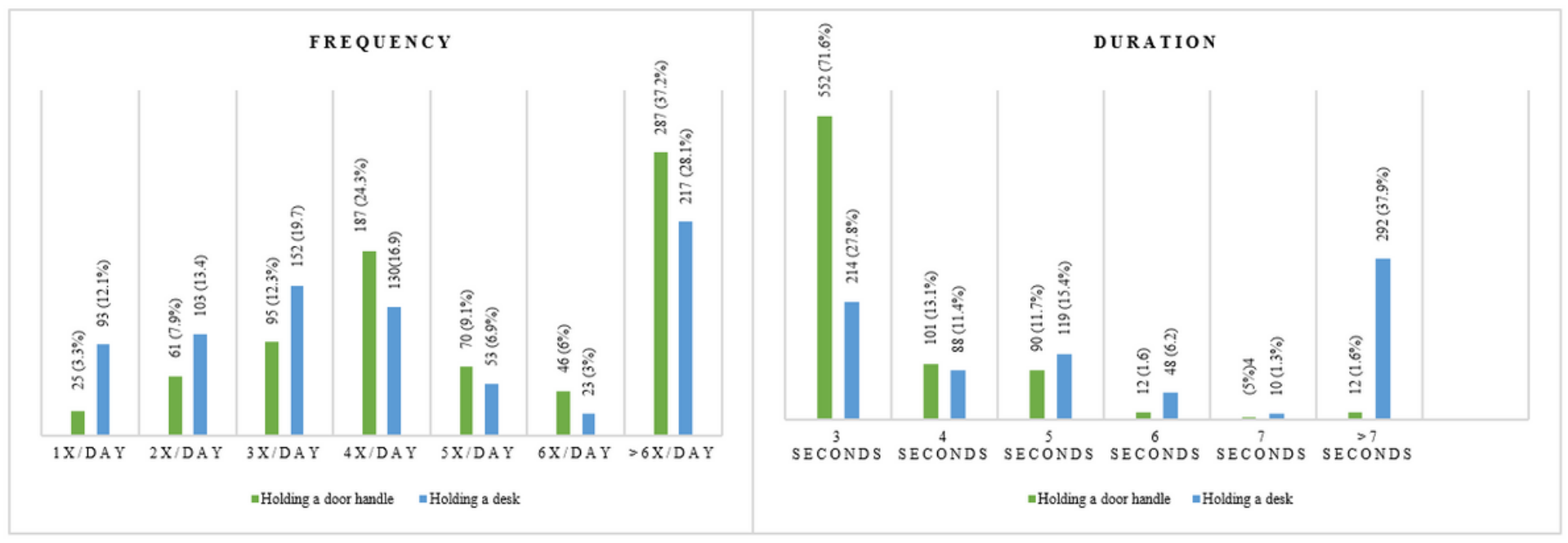

\section{Figure 6}

The trend of holding an object 


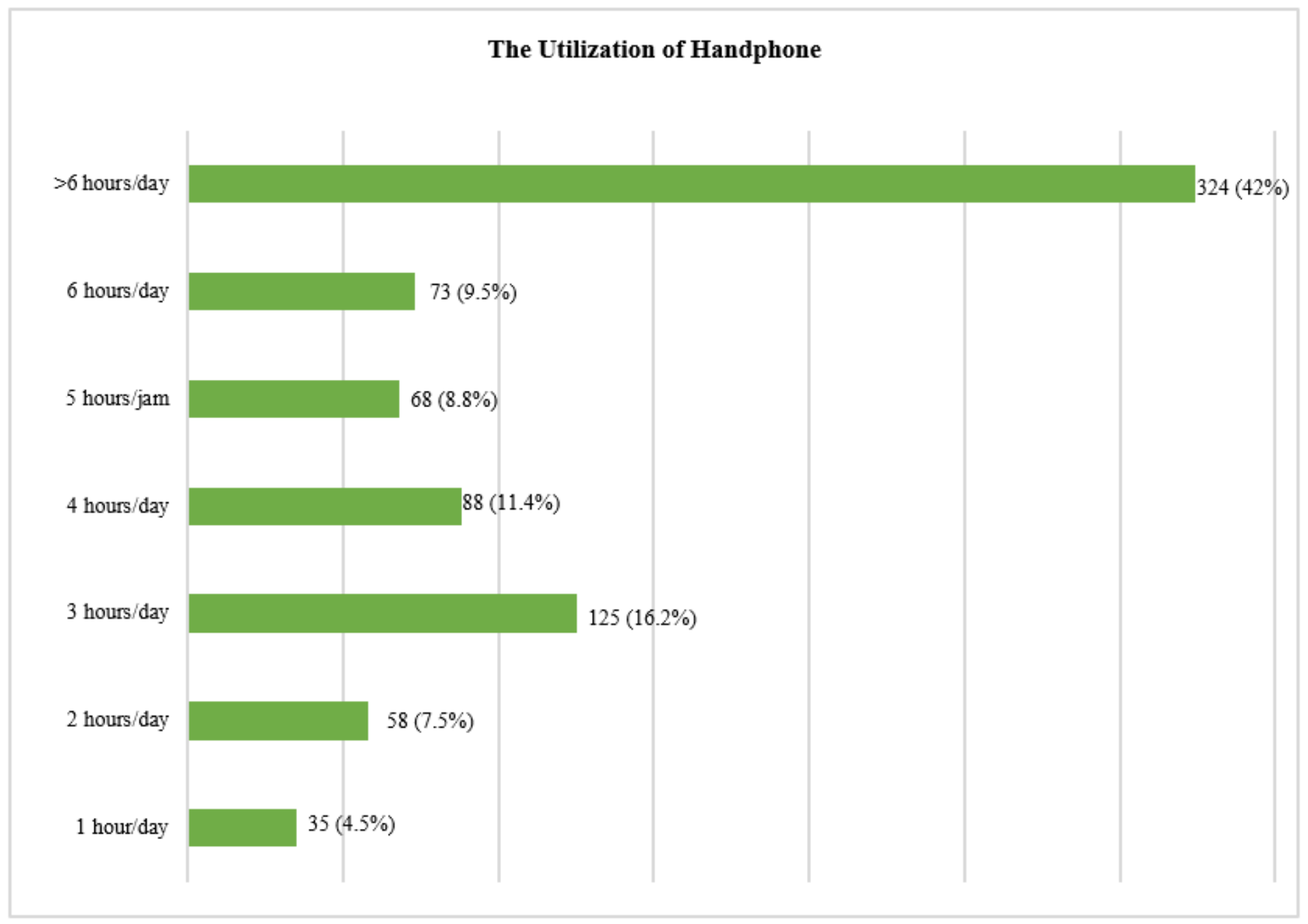

Figure 7

The use of handphone 


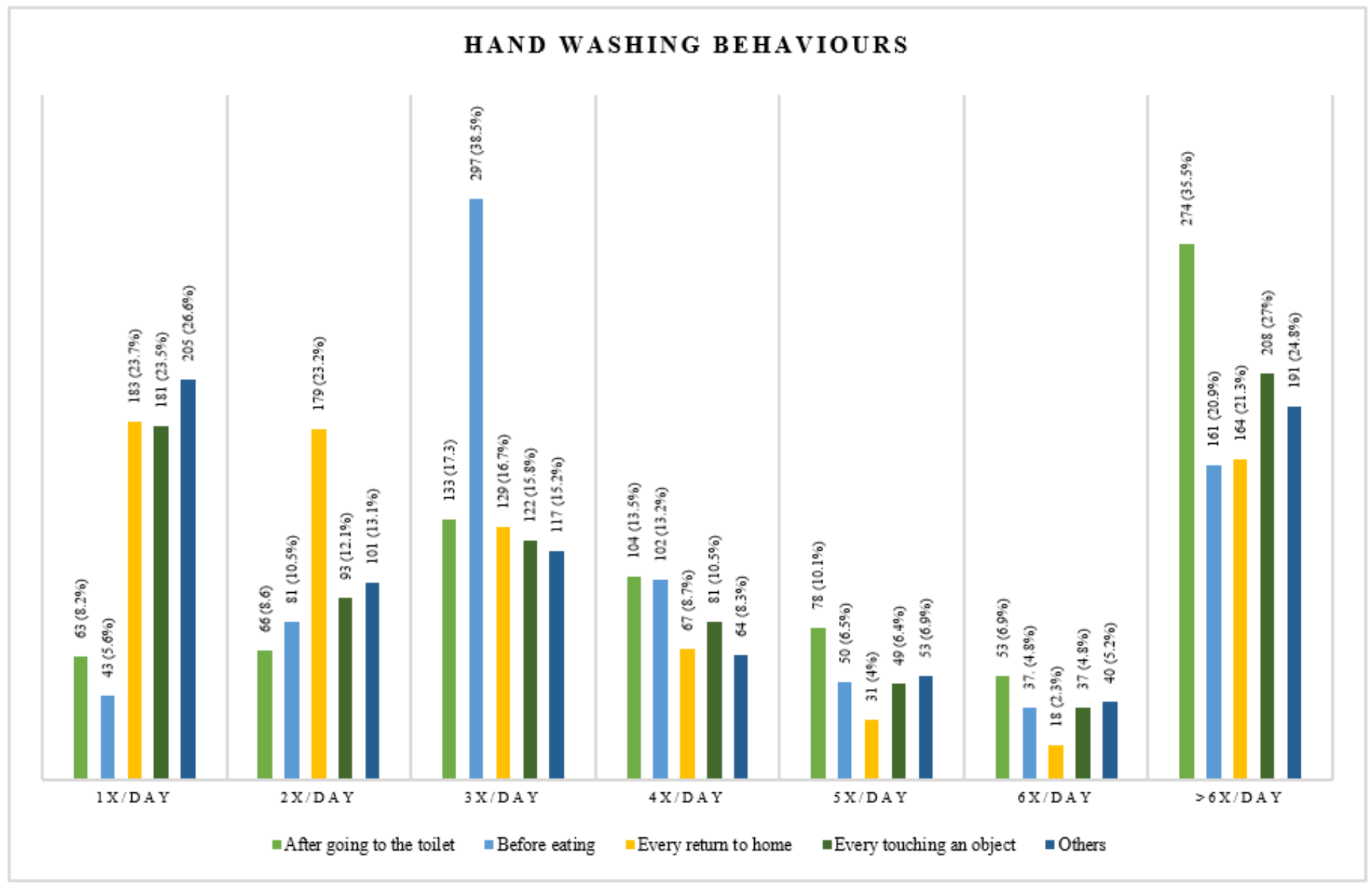

Figure 8

Hand washing behaviours 


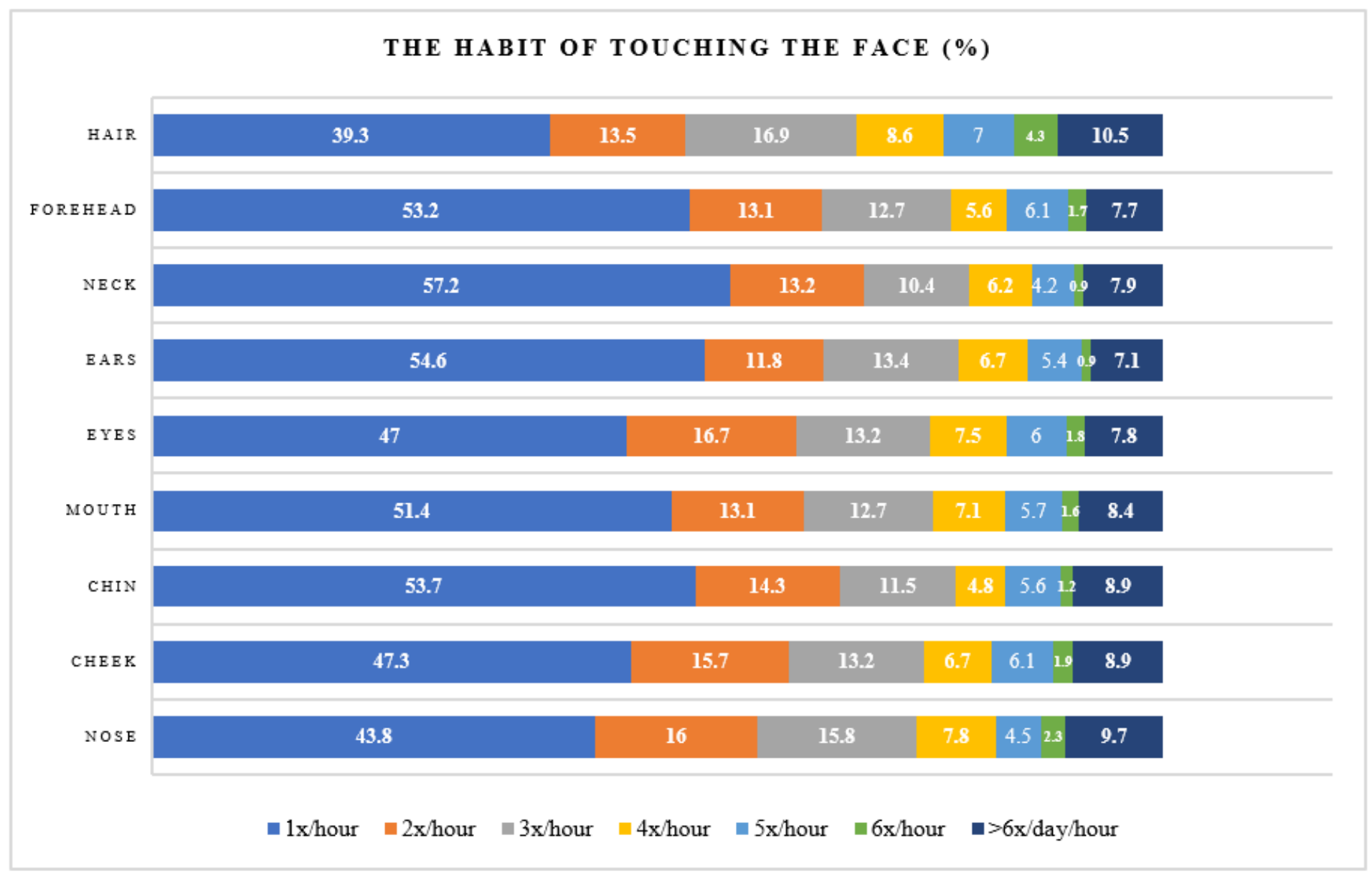

\section{Figure 9}

The percentage of touching the face habits

\section{Supplementary Files}

This is a list of supplementary files associated with this preprint. Click to download.

- QuetionnaireOnlineSurveyDK3NCovid19.pdf 